\title{
ANALISIS KETERLAMBATAN PENGIRIMAN MATERIAL BETON (STUDI KASUS PROYEK BREEZE TOWER, BINTARO PT. TATAMULIA NUSANTARA INDAH)
}

\author{
Andre Feliks Setiawan ${ }^{1}$, Nadya Dwivania ${ }^{2}$, Michael Louis Sunaris ${ }^{3}$ \\ ${ }^{1}$ Dosen, Program Studi Manajemen Dan Rekayasa Konstruksi, \\ Universitas Agung Podomoro \\ ${ }^{2}$ Alumni, Program Studi Manajemen Dan Rekayasa Konstruksi, \\ Universitas Agung Podomoro \\ ${ }^{3}$ Mahasiswa, Program Studi Teknik Sipil, Fakultas Teknik, Universitas Kristen Maranatha \\ Email: michaellouis2410@yahoo.com
}

\begin{abstract}
ABSTRAK
Setiap proyek konstruksi mempunyai kompleksitas yang tinggi, dan dibutuhkan kerjasama dari semua pihak yang terlibat untuk mencapai keberhasilan suatu proyek. Umumnya, setiap proyek mempunyai rencana dan jadwal pelaksanaan, kapan proyek harus dimulai dan berapa lama proyek akan selesai. Ada tiga aspek yang harus diperhatikan dalam rangka memenuhi target proyek, yaitu biaya, mutu, dan waktu. Pembuatan rencana proyek konstruksi harus memperhatikan ketiga aspek tersebut dan mengacu pada perkiraan yang ada pada saat rencana pembangunan dibuat. Seiring berjalannya waktu, terjadi ketidaksesuaian antara rencana yang dibuat dengan realisasi yang ada di lapangan, sehingga dampak yang terjadi adalah keterlambatan pelaksanaan pekerjaan yang disertai dengan meningkatnya biaya pelaksanaan pekerjaan. Salah satu masalah yang sering terjadi di Proyek Breeze Tower adalah keterlambatan pengiriman beton dari pihak supplier. Dalam jangka waktu satu minggu, pekerjaan pengecoran tiga belas kali terlambat dari schedule rencana pengecoran. Kondisi ini membutuhkan manajemen resiko untuk meminimalisir keterlambatan serta pemborosan biaya. Kontraktor tentunya menginginkan proyek berjalan tepat waktu dan sesuai dengan perencanaan, sehingga dapat menguntungkan baik kontraktor, maupun pemilik proyek. Dalam rangka mencapai target penyelesaian proyek sesuai pada waktunya, di dalam proyek Breeze Tower ini dilakukan langkah-langkah untuk pencegahan keterlambatan progress proyek.

Kata Kunci: jadwal pelaksanaan, keterlambatan, manajemen resiko.
\end{abstract}

\begin{abstract}
Every construction project has a high complexity, and it requires cooperation from all parties involved to achieve the success of a project. Generally, each project has a plan and implementation schedule, when the project must begin and how long the project will be completed. There are three aspects that must be considered in order to meet project targets, namely cost, quality, and time. Making a construction project plan must pay attention to these three aspects and refer to the estimates that existed at the time the development plan was made. As time went on, there was a mismatch between the plans made with the realization in the field, so that the impact that occurred was the delay in the implementation of the work accompanied by the increase in the cost of carrying out the work. One of the problems that often occurs in the Breeze Tower Project is the late delivery of concrete from the supplier. Within a period of one week, casting work is thirteen times late from the planned casting schedule. This condition requires risk management to minimize delays and waste of money. The contractor certainly wants the project to run on time and in accordance with the plan, so that it can benefit both the contractor and the project owner. In order to achieve the project completion target in time, in the Breeze Tower project steps were taken to prevent project progress delays.
\end{abstract}

Keywords: time schedule, delay, risk managemen. 


\section{PENDAHULUAN}

Setiap proyek konstruksi mempunyai kompleksitas yang tinggi, dan dibutuhkan kerjasama dari semua pihak yang terlibat untuk mencapai keberhasilan suatu proyek. Umumnya, setiap proyek mempunyai rencana dan jadwal pelaksanaan, kapan proyek harus dimulai dan berapa lama proyek akan selesai. Ada tiga aspek yang harus diperhatikan dalam rangka memenuhi target proyek, yaitu biaya, mutu, dan waktu. Pembuatan rencana proyek konstruksi harus memperhatikan ketiga aspek tersebut dan mengacu pada perkiraan yang ada pada saat rencana pembangunan dibuat. Seiring berjalannya waktu, terjadi ketidaksesuaian antara rencana yang dibuat dengan realisasi yang ada di lapangan, sehingga dampak yang terjadi adalah keterlambatan pelaksanaan pekerjaan yang disertai dengan meningkatnya biaya pelaksanaan pekerjaan.

Salah satu masalah yang sering terjadi di Proyek Breeze Tower adalah keterlambatan pengiriman beton dari pihak supplier. Dalam jangka waktu satu minggu, pekerjaan pengecoran tiga belas kali terlambat dari schedule rencana pengecoran. Kondisi ini membutuhkan manajemen resiko untuk meminimalisir keterlambatan serta pemborosan biaya. Kontraktor tentunya menginginkan proyek berjalan tepat waktu dan sesuai dengan perencanaan, sehingga dapat menguntungkan baik kontraktor, maupun pemilik proyek. Dalam rangka mencapai target penyelesaian proyek sesuai pada waktunya, di dalam proyek Breeze Tower ini dilakukan langkah-langkah untuk pencegahan keterlambatan progress proyek. Adapun lokasi dari proyek Apartemen Breeze Tower terletak di Jl. Bintaro Utama Sektor 3A Tangerang Selatan, Banten (Gambar 1).

Rumusan masalah dari penelitian ini adalah untuk mengetahui faktor-faktor penyebab keterlambatan supplier beton, serta mengetahui akibat yang ditimbulkan dari keterlambatan penyediaan beton. Faktor-faktor yang menyebabkan keterlambatan pelaksanaan proyek diharapkan menjadi acuan bagi pemilik proyek atau kontraktor dalam merencanakan proyek agar selesai tepat waktu. Oleh karena itu, penelitian ini difokuskan untuk menganalisis keterlambatan pengiriman material, baik dari penyebab, akibat, maupun solusi pencegahannya. Manfaat dari analisis kasus keterlambatan penyediaan beton ini adalah untuk menambah pengetahuan mengenai keterlambatan penyediaan material di dalam suatu proyek, menjadi sumber referensi untuk analisis lebih lanjut, serta untuk meningkatkan kemampuan dalam menganalisis suatu topik. 


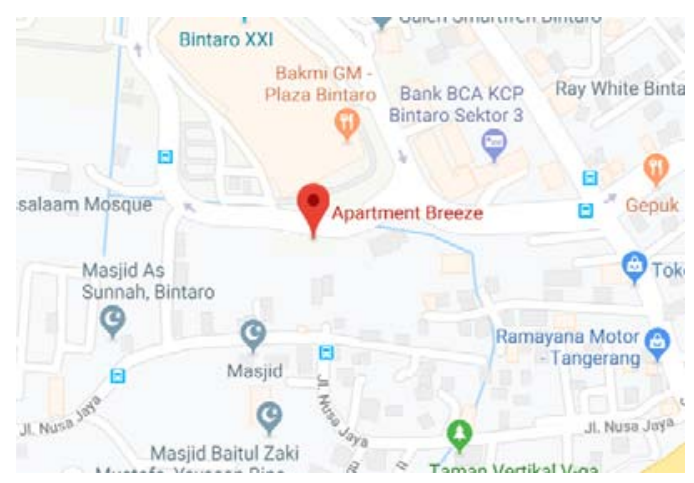

Gambar 1. Lokasi Studi Area

\section{LANDASAN TEORI}

Dalam penelitian ini diperlukan kajian atau landasan teori yang mendukung seperti definisi beton dan material penyusun beton dan fungsinya. Menurut SNI 03-2834-2000, beton adalah campuran antara semen Portland atau semen hidrolik yang lain, agregat halus, agregat kasar dan air, dengan atau tanpa bahan tambahan yang membentuk massa padat (BSN, 2000). Material yang digunakan dalam penyusunan beton adalah sebagai berikut:

\section{- $\quad$ Semen Portland}

Semen yang merupakan salah satu bahan dasar pembuatan beton tergolong ke dalam jenis semen hidrolis. Jenis semen hidrolis yang banyak digunakan hingga saat ini adalah semen Portland. Bahan-bahan dasar semen Portland terdiri dari kapur $(\mathrm{CaO})$, silika ( $\mathrm{SiO} 2)$, alumina (A12O3), dan oksida besi (Fe2O3). Secara umum sesuai dengan standar dari American Society for Testing and Materials (ASTM), jenis semen dikategorikan menjadi lima jenis:

- Tipe I: jenis semen biasa yang digunakan pada pekerjaan konstruksi umum,

- Tipe II: jenis semen modifikasi dari semen tipe I, yang memiliki panas hidrasi lebih rendah dan dapat tahan dari beberapa jenis serangan sulfat,

- Tipe III: jenis semen yang dapat menghasilkan kuat tekan beton awal yang tinggi,

- Tipe IV: jenis semen yang mampu menghasilkan panas hidrasi yang rendah, sehingga cocok digunakan pada proses pengecoran struktur beton yang masif,

- Tipe V: jenis semen yang digunakan untuk struktur-struktur beton yang memerlukan ketahanan yang tinggi dari serangan sulfat (Setiawan, 2016).

- Air 
Air diperlukan pada pembentukan semen yang berpengaruh terhadap sifat kemudahan pengerjaan adukan beton (workability), kekuatan, susut dan keawetan beton. Air yang diperlukan untuk bereaksi dengan semen hanya sekitar $25 \%$ dari berat semen saja, namun dalam kenyataannya nilai faktor air semen yang dipakai sulit jika kurang dari 0,35. Kelebihan air dari jumlah yang dibutuhkan dipakai sebagai pelumas, tambahan air ini tidak boleh terlalu banyak karena kekuatan beton menjadi rendah dan beton menjadi keropos.

\section{- Agregat (Pasir dan kerikil)}

Agregat adalah butiran mineral alami yang berfungsi sebagai bahan pengisi dalam campuran mortar atau beton. Kira-kira $70 \%$ volume mortar atau beton diisi oleh agregat. Agregat sangat berpengaruh terhadap sifat-sifat mortar atau beton, sehingga pemilihan agregat merupakan suatu bagian penting dalam pembuatan mortar atau beton.

\section{- Admixture}

Bahan campuran tambahan (admixtures) adalah bahan yang bukan air, agregat maupun semen yang ditambahkan ke dalam campuran sesaat atau selama pencampuran. Fungsi dari bahan ini adalah untuk mengubah sifat-sifat beton atau pasta semen agar menjadi cocok untuk pekerjaan tertentu, atau ekonomis untuk tujuan lain seperti menghemat energi (Nawy, 1996).

\section{STUDI KASUS}

Dalam konteks penjadwalan, terdapat dua perbedaan, yaitu waktu (Time) dan kurun waktu (duration). Bila waktu menyatakan siang/malam, sedangkan kurun waktu atau durasi menunjukan lama waktu yang dibutuhkan dalam melakukan suatu kegiatan, seperti lamanya waktu kerja dalam satu hari adalah 8 Jam. Melakukan durasi suatu kegiatan bisanya dilandasi volume pekerjaan dan produktivitas kelompok pekerja dalam menyelesaikan suatu pekerjaan. Produktivitas didapat dari pengalaman kelompok pekerja melakukan suatu kegiatan yang telah dilakukan sebelum atau database perusahaan.

Menurut Hansen (2015), karakteristik proyek konstruksi adalah kompleksitasnya, terutama yang berkaitan dengan waktu pelaksanaan pekerjaan. Hampir selalu terdapat kondisi-kondisi yang memengaruhi waktu pelaksanaan pekerjaan di lapangan. Terdapat empat kategori keterlambatan dalam industri konstruksi, yaitu: 
1. Kritis atau tidak kritis (critical or non-critical),

2. Dimaklumi atau tidak dimaklumi (excusable or non-excusable),

3. Dapat dikompensasi atau tidak dapat dikompensasi (compensable or noncompensable),

4. Yang terjadi berbarengan atau tunggal (concurrent or non-concurrent).

Keterlambatan yang terjadi di dalam proyek Breeze Tower ini termasuk keterlambatan kritis, karena memengaruhi durasi waktu penyelesaian pekerjaan, namun termasuk compensable. Hal ini dikarenakan keterlambatan yang terjadi bukan diakibatkan oleh kontraktor, namun merupakan kesalahan dari supplier. Oleh karena itu, kontraktor berhak mengajukan klaim atas biaya kepada supplier beton.

Dalam pemesanan material, Kontraktor TATA Breeze Tower melakukan pemesanan material melalui kantor pusat, kemudian kantor pusat yang memesan ke supplier. Setelah itu, supplier akan memproses pemesanan material tersebut. TATA akan memberikan Surat Penerimaan Barang (SPB) ke supplier, sedangkan supplier memberikan bukti penyerahan barang (Docket) kepada staff logistik di proyek. Gambar 2 merupakan alur proses pemesanan material pada proyek TATA.

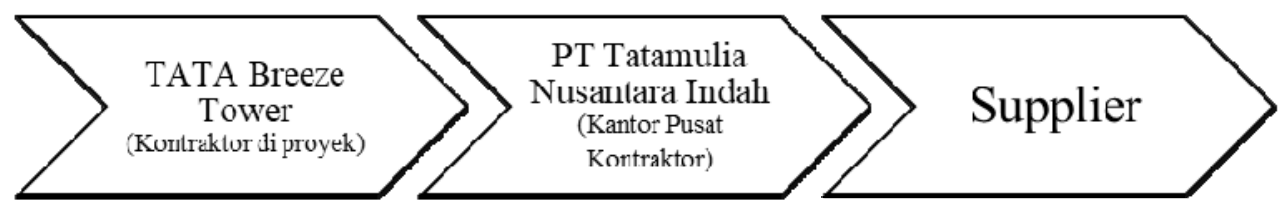

Gambar 2. Alur Proses Pemesanan Material

Pada saat proyek belum dimulai, dilakukan proses trial mix untuk menguji kualitas dan proporsi campuran beton. Proses trial mix ini melibatkan supplier, kontraktor, konsultan MK, dan pemilik proyek. Proses trial mix dimaksudkan untuk menguji kualitas air, semen, agregat kasar dan agregat halus yang digunakan, menguji nilai slump, kekuatan beton pada umur tujuh hari, empat belas hari, 21 hari, dan 28 hari. Setelah semua pengujian tersebut memenuhi persyaratan, maka material beton dari supplier tersebut disetujui untuk digunakan di proyek Breeze Tower. Sedangkan untuk proses pengecoran di lapangan, kontraktor melakukan pengecekan sebanyak dua kali, yaitu pengecekan di lapangan dan pengecekan di batching plant itu sendiri. Pengecekan di lapangan (tes slump), melibatkan pihak kontraktor dan pihak owner, sedangkan pengecekan di batching plant melibatkan pihak supplier dan pihak kontraktor. 
Untuk mengatasi kompleksitas proyek dengan durasi yang panjang, khususnya di proyek Breeze Tower, dapat dilakukan teknik pengendalian, dimana salah satunya adalah manajemen resiko. Menurut Ervianto (2004), untuk menjaga kesesuaian antara perencanaan dan pelaksanaan di lapangan, diperlukan pengendalian (manajemen) proyek. Dengan perencanaan dan pengendalian yang baik terhadap kegiatan-kegiatan yang ada, maka terjadinya keterlambatan jadwal yang mengakibatkan biaya proyek dapat dihindari. Kendrick (2015) mengatakan bahwa manajemen resiko dibutuhkan bukan untuk menghapus semua resiko dan ketidakpastian di proyek, namun untuk mengendalikan resiko yang terjadi di proyek. Hal ini berarti dibutuhkan pemahaman sumber resiko dan penanganannya yaitu mitigasi resiko untuk meminimialisir kegagalan dan meningkatkan kemungkinan keberhasilan proyek. Tahap-tahap dalam manajemen resiko adalah seperti pada Gambar 3.

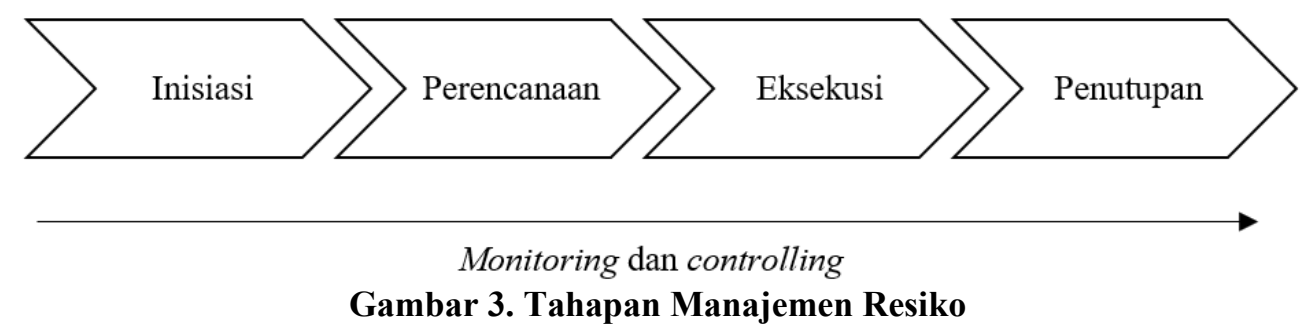

Pada proyek Breeze Tower ini, kontraktor telah menerapkan tahapan manajemen resiko dengan baik dan berhasil. Hal ini terbukti dengan tidak adanya keterlambatan proyek dari master schedule. Monitoring pengecoran proyek Breeze Tower dilakukan pada tanggal 18 September 2017 hingga 24 September 2017, dimana data tersebut dilampirkan pada lampiran C. Hasil pengamatan kemudian direkapitulasi ke dalam Gambar 4, sehingga didapatkan analisis aktualisasi jadwal dan volume pengecoran pada minggu ke-37. Hasil analisisnya adalah sebagai berikut:

1. Pengecoran kolom lantai 18 dan lantai 19 di Zona 2 mengalami keterlambatan dua hari dari jadwal yang direncanakan dan kelebihan volume beton yang dicor sebanyak $1 \mathrm{~m}^{3}$.

2. Pengecoran slab dan balok lantai 18 di Zona 3 mengalami keterlambatan tiga hari dari jadwal yang direncanakan dan kelebihan volume beton yang dipakai sebanyak 5 $\mathrm{m}^{3}$. 
3. Pengecoran kolom lantai 18 dan lantai 19 di Zona 3 mengalami keterlambatan dua hari dari jadwal yang direncanakan. Sedangkan volume beton terpakai sama dengan yang direncanakan.

4. Pengecoran slab dan balok lantai 19 di Zona 1 tidak mengalami keterlambatan. Sedangkan volume beton yang dipakai lebih sebanyak $4 \mathrm{~m}^{3}$ dari yang direncanakan.

5. Pengecoran kolom lantai 19 dan lantai 20 di Zona 1 tidak mengalami keterlambatan dan volume beton terpakai sama dengan yang direncanakan.

6. Pengecoran slab dan balok lantai 19 di Zona 2 tidak mengalami keterlambatan. Sedangkan volume beton yang dipakai lebih sebanyak $5 \mathrm{~m}^{3}$ dari yang direncanakan.

7. Pengecoran kolom lantai 19 dan lantai 20 di Zona 2 tidak mengalami keterlambatan. Sedangkan volume beton yang dipakai lebih banyak $6 \mathrm{~m}^{3}$ dari yang direncanakan.

8. Pengecoran Shear Wall (SW) 1 dan SW 2 lantai 21 dan lantai 22 mengalami keterlambatan lebih dari dua hari dari jadwal yang direncanakan.

9. Pengecoran SW 3 dan SW 4 lantai 21 dan lantai 22 mengalami keterlambatan dua hari dari jadwal yang direncanakan. Sedangkan volume beton terpakai sama dengan yang direncanakan.

10. Pengecoran tangga kedua lantai 11 dan lantai 11A mengalami keterlambatan sebanyak lima hari dari jadwal yang direncanakan. Sedangkan volume beton terpakai sama dengan yang direncanakan.

11. Pengecoran tangga pertama lantai 11 dan lantai 11A mengalami keterlambatan dua hari dari jawal yang direncanakan. Sedangkan volume beton terpakai sama dengan yang direncanakan.

12. Pengecoran tangga kedua lantai $11 \mathrm{~A}$ dan lantai 12 mengalami keterlambatan dari jadwal yang direncanakan.

13. Pengecoran slab dan balok lantai under ground (UG) area kolam renang mengalami keterlambatan lebih dari 5 hari dari jadwal yang direncanakan.

14. Pengecoran pile cap dan tie beam mengalami keterlambatan sebanyak 2 hari dari jadwal yang direncanakan. Seharusnya pengecoran dilakukan pada tanggal 19 September 2017 dan 21 September 2017, namun pada kenyataannya pengecoran dilakukan tanggal 21 September 2017 dan 22 September 2017. Sedangkan pengecoran pada tanggal 24 September 2017 mengalami kemajuan dari jadwal yang direncanakan, sehingga volume beton terpakai mengalami kelebihan $21 \mathrm{~m}^{3}$ dari yang direncanakan. 


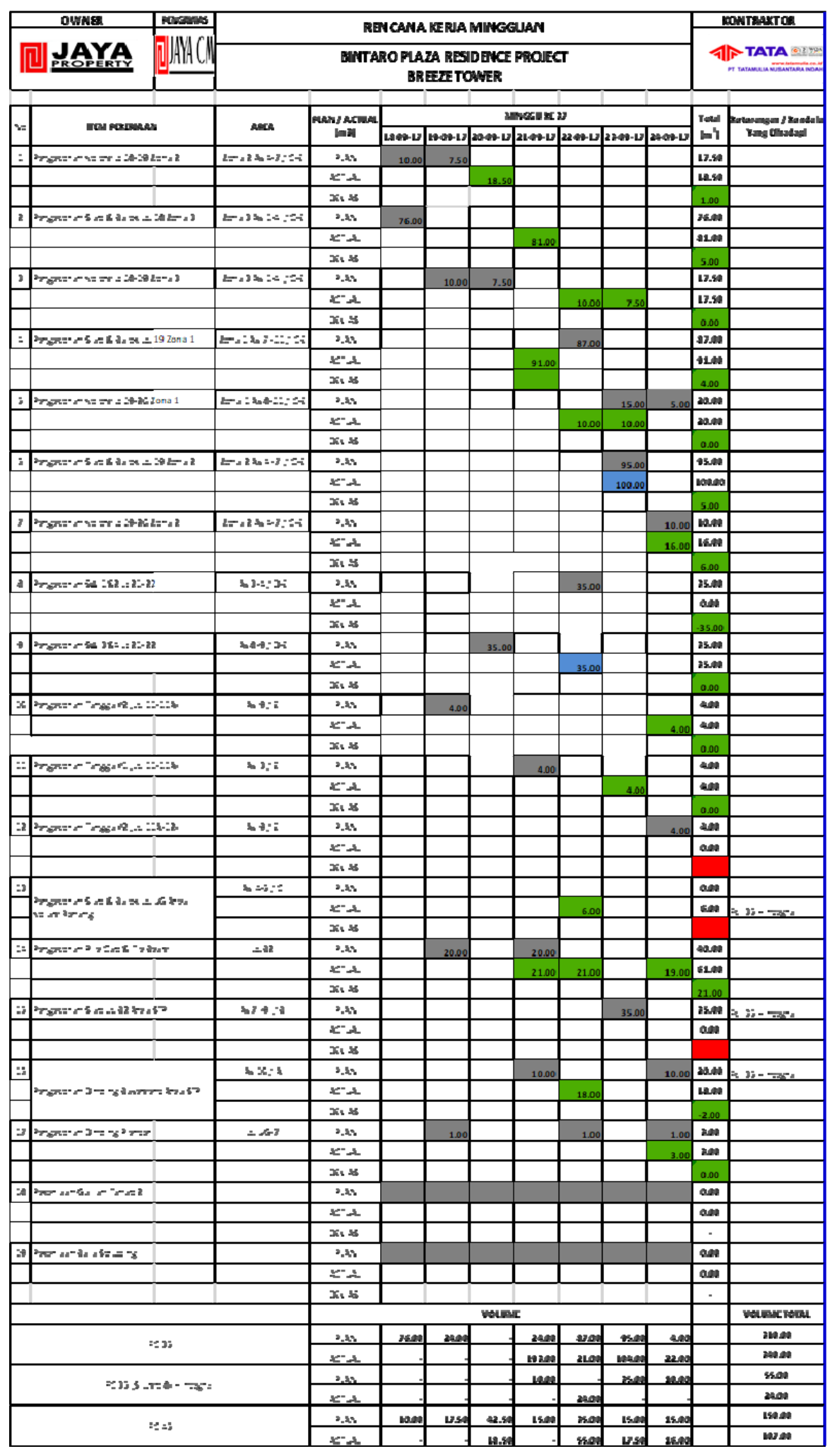

Gambar 4. Schedule Pengecoran Proyek Breeze Tower

Analisis Keterlambatan Pengiriman Material Beton

(Studi Kasus Proyek Breeze Tower, Bintaro PT. Tatamulia Nusantara Indah)

(Andre Feliks Setiawan, Nadya Dwivania, Michael Louis Sunaris) 
15. Pengecoran area slab lantai basement 2 area Sewage Treatment Plant (STP) mengalami keterlambatan lebih dari 1 hari dari jadwal yang direncanakan.

16. Pengecoran dinding basement area STP mengalami keterlambatan sebanyak satu hari dari jawal yang direncanakan. Sedangkan volume beton terpakai lebih sedikit 2 $\mathrm{m}^{3}$ dari yang direncanakan.

17. Pengecoran dinding planter lantai UG mengalami keterlambatan sebanyak 5 hari dari jadwal yang direncanakan. Sedangkan volume beton terpakai sama dengan yang direncanakan.

18. Untuk pekerjaan galian tahap 2 dan pekerjaan baja strutting belum dilaksanakan maupun direncanakan di minggu ke-37.

19. Total volume pengecoran beton yang terpakai adalah sebagai berikut:

- Mutu beton ( $f_{c}^{\prime}$ ) $35 \mathrm{MPa}$ adalah sebanyak $340 \mathrm{~m}^{3}$, sedangkan volume yang dipesan adalah $310 \mathrm{~m}^{3}$.

- Mutu beton ( $f_{c}^{\prime}$ ) $35 \mathrm{MPa}$ (slump 8) dan integral adalah sebanyak $24 \mathrm{~m}^{3}$, sedangkan volume yang dipesan adalah $55 \mathrm{~m}^{3}$.

- Mutu beton $\left(f_{c}^{\prime}\right) 45 \mathrm{MPa}$ adalah sebanyak $150 \mathrm{~m}^{3}$, sedangkan volume beton yang dipesan adalah $107 \mathrm{~m}^{3}$.

\section{KESIMPULAN DAN REKOMENDASI}

Hasil analisis menunjukkan bahwa dalam penyediaan material beton terdapat berbagai kendala. Kendala-kendala tersebut di antaranya adalah kesulitan dalam pengambilan material, plant armada yang sibuk mengurusi beberapa proyek sekaligus, serta kekurangan armada supplier beton yang mengakibatkan keterlambatan schedule pengecoran. Akibat dari keterlambatan tersebut menimbulkan biaya yang berlebih, keterlambatan pengecoran, dan juga keterlambatan progress proyek. Namun, keterlambatan yang terjadi diminimalisir dengan perencanaan manajemen resiko yang baik sebelum pelaksanaan proyek, sehingga keterlambatan tidak berdampak besar pada master schedule. Rekomendasi yang dapat diberikan terkait permasalahan keterlambatan supplier material yaitu dalam pemilihan supplier harus mempertimbangkan track record supplier serta kemampuan supplier untuk menyediakan material dalam volume yang besar. 


\section{DAFTAR PUSTAKA}

1. Departemen Permukiman dan Prasarana Wilayah. (2004). Survai Pencacahan Lalu Lintas dengan cara Manual. Jakarta: Departemen Permukiman dan Prasarana Wilayah.

2. Badan Standarisasi Nasional (2000). Tata Cara Pembuatan Rencana Campuran Beton Normal. Jakarta: BSN.

3. Ervianto, Wulfram I. (2004). Teori-Aplikasi Manajemen Proyek Konstruksi. Yogyakarta: Andi.

4. Hansen, Seng (2015). Manajemen Kontrak Konstruksi. Jakarta: PT. Gramedia Pustaka Utama.

5. Kendrick, Tom (2015). Identifying and Managing Project Risk. USA: AMACOM.

6. Setiawan, Agus (2016). Perancangan Struktur Beton Bertulang. Jakarta: Erlangga.

7. Nawy, E.G (1996). Reinforced Concrete: A Fundamental Approach. USA: Prentice Hall. 